\title{
Multi-spatial contamination of environmental aquatic matrices with Cryptosporidium: a climate, health, and regulatory framework for the Philippines
}

Frederick R. Masangkay ${ }^{1,2^{*}}$ D, Giovanni D. Milanez ${ }^{1,2}$, Voravuth Somsak ${ }^{1}$, Manas Kotepui ${ }^{1}$, Jitbanjong Tangpong ${ }^{1}$ and Panagiotis Karanis ${ }^{3,4^{*}}$

\begin{abstract}
Background: Cryptosporidium is a waterborne global pathogen causing diarrhea primarily in infants and immunocompromised individuals. The Philippines is a tropical country susceptible to the influences of climate change and water crises. To date, the country has no existing epidemiologic data, regulation, or strategy for monitoring Cryptosporidium in freshwater systems. We, therefore, endeavored to provide evidence on the multi-spatial contamination of Cryptosporidium in environmental aquatic matrices using low-cost, user-friendly, and sustainable strategies and submit implications on the presence of Cryptosporidium in freshwater systems in a climate, health, and regulatory framework.

Results: Here, we present the microscopic detection of Cryptosporidium oocysts in low-volume (50 mL) environmental samples of surface water (SW), sediments (BW), and substrate-associated biofilm (SAB) and in $1 \mathrm{~L}$ bulk SW investigated by PCR. The multi-spatial distribution of Cryptosporidium oocysts in the low-volume $(50 \mathrm{ml})$ aquatic matrices based on microscopy was highest at 69\% (20/29) in SW and lowest at 50\% (13/26) in BW. Immunofluorescence technique provided the highest microscopic positivity rate with 59\% (17/29), 38\% (10/26), and 50\% (10/20) detection in SW, BW, and SAB, respectively. The detection and identification of Cryptosporidium in $1 \mathrm{~L}$ bulk SW by PCR and sequence analysis was recorded in total at $21 \%(6 / 29)$ in sampling sites where the differential identification of $C$. parvum, C. hominis, and Cryptosporidium spp. was 7\% (2/29), 10\% (3/29), and 3\% (1/29), respectively.
\end{abstract}

Conclusions: We report the microscopical and first molecular epidemiologic data of Cryptosporidium from the most significant environmental freshwater systems in the Philippines. The presence of the two main human and animal pathogenic species C. parvum and C. hominis from the largest lakes and major water reservoirs in the country calls for sustainable solutions in safeguarding the quality of freshwater resources in a climate, health, and regulatory approach.

Keywords: Cryptosporidium, Biofilms, Climate, Sediments, Lakes, Freshwater, Philippines

*Correspondence: fmasangkay@feu.edu.ph; karanis.p@unic.ac.cy

2 Department of Medical Technology, Institute of Arts and Sciences, Far Eastern University, Manila 1015, Philippines

${ }^{4}$ Department of Basic and Clinical Sciences, University of Nicosia Medical

School, Nicosia 2408, Cyprus

Full list of author information is available at the end of the article

\section{Background}

Cryptosporidiosis is the second leading cause of infantile mortality next to rotavirus infection [1] and was listed in the 'Neglected Disease Initiative' of the World Health Organization [2]. Cryptosporidium has a low infectious dose (1-10 oocysts) and causes morbidity in both the immunocompromised and immunocompetent populations $[3,4]$. 
Cryptosporidium ranks first in parasitic protozoans causing waterborne infections in developed and developing countries $[5,6]$. The common practice in water quality assessment is the testing of surface water samples used for drinking water preparation. Water sediments were explored but in the form of sludge from wastewater treatment facilities $[7,8]$ and rarely in environmental sampling [9]. Investigators involved in such studies have, therefore, recommended the simultaneous testing of disturbed water samples as a by-product of zoonotic and anthroponotic activities [10].

Biofilms may be formed at solid-liquid (substrateassociated) as well as water-air (floating) interface, and may harbor pathogenic microorganisms [11]. Floating biofilms, for example, are mainly composed of Gramnegative bacteria, which produce a polysaccharide matrix to hold the microcosm together [12], and, through time, potentially trap and accumulate waterborne pathogens [13-15].

Hundreds of efforts have been described in addressing selected components of the problems encountered in the monitoring of Cryptosporidium in water with the objectives to define the quantity, viability, and human infectivity of oocysts [16]. This provides a quantitative understanding of the public health risks concerning water supply and water treatment strategies, which can provide foundations for water reservoir management, treatment designs, operation, supply, monitoring, and regulation [17].

The provision of low-cost, user-friendly, and sustainable recovery methods for Cryptosporidium in high (50$100 \mathrm{~L}$ ) and standard-volume (5-10 L) water samples like flotation and flocculation have been previously described [16, 18-23]. However, Cryptosporidium identification in water samples still proves to be challenging and requires expertise in identification through a plethora of technical methodologies [24].

According to the WHO Drinking water key facts of 2018 , contaminated drinking water is the cause of diarrhoeal deaths estimated to be at 502,000 per year. 844 million people lack access to drinking water service, and 423 million utilize well and spring water with 159 million still dependent on untreated surface water from lakes, ponds, rivers, and streams. Daunting challenges to the access of clean drinking water are climate change, population growth, demographic changes, and urbanization, thereby leading to a forecast of having the world's population living in water-stressed areas by 2025 [25]. The first mention of climate change in any medical literature was more than 30 years ago by Professor Alexander Leaf in a 1989 article titled 'Potential health effects of global climatic and environmental changes' [26]. Fast forward to the present, a clear understanding of climate change direction, magnitude, and tempo is still elusive or unknown to the general population and is barely studied within the framework of human health. The Southeast Asian region and its populace are highly susceptible to the health effects of climate change and water crises [27]. To date, research that delves into the relationship of non-communicable and communicable diseases with the changing climate and how it influences the availability of and access to clean water is still a rarity [28].

The Republic of the Philippines, at present, has limited literature on Cryptosporidium, and no molecular identification in water supplies exist $[29,30]$. Therefore, we aimed to establish inceptive data at a nationwide scale on the microscopic and molecular prevalence of Cryptosporidium from the largest lakes and major water reservoirs in the Philippines, using low-cost, user-friendly, and sustainable methods, while discussing our findings through the lenses of climate, health, and regulation to unravel its implications.

\section{Materials and methods Study sites}

The study sites covered the three major Islands of the Philippines namely: Luzon $(n=13)$, Visayas $(n=3)$, Mindanao $(n=6)$, and a study site in the MIMAROPA (Mindoro, Marinduque, Romblon, and Palawan) region $(n=1)$. Characteristics of the study sites such as surface area, elevation in meters above sea level (MASL), coordinates, water temperature, average precipitation level, and date and time of collection are listed in Additional file 1 . The 23 study sites were mainly composed of the largest lakes and major freshwater reservoirs in the Philippines (Fig. 1). These study sites were further divided into sampling sites $(n=29)$ composed of sampling points $(n=72)$ (Additional files 2 and 3 ) and were chosen based on (1) significance to the Philippines and its inhabitants, (2) road access, (3) presence of human settlements, (4) anthropogenic activities as well as tourism and recreational activities, and (5) presence of aquaculture.

\section{Sample collection, processing, and microscopy panel}

Surface water samples (SW) were collected in $50 \mathrm{~mL}$ sterile polyethylene containers from no more than $30 \mathrm{~cm}$ below the water surface. Sediments with bottom water (BW) were collected from a water depth of $1 \mathrm{~m}$ along the shoreline that was composed of one-part sediments and four-part bottom water. Substrate-associated biofilms (SAB) were harvested from an area with a depth of $1 \mathrm{~m}$ along the shoreline where aquatic plants and rocks were present. Short segments of small aquatic plants were collected and washed with sterile distilled water to remove non-adherent cells and cut to small portions to fit inside 


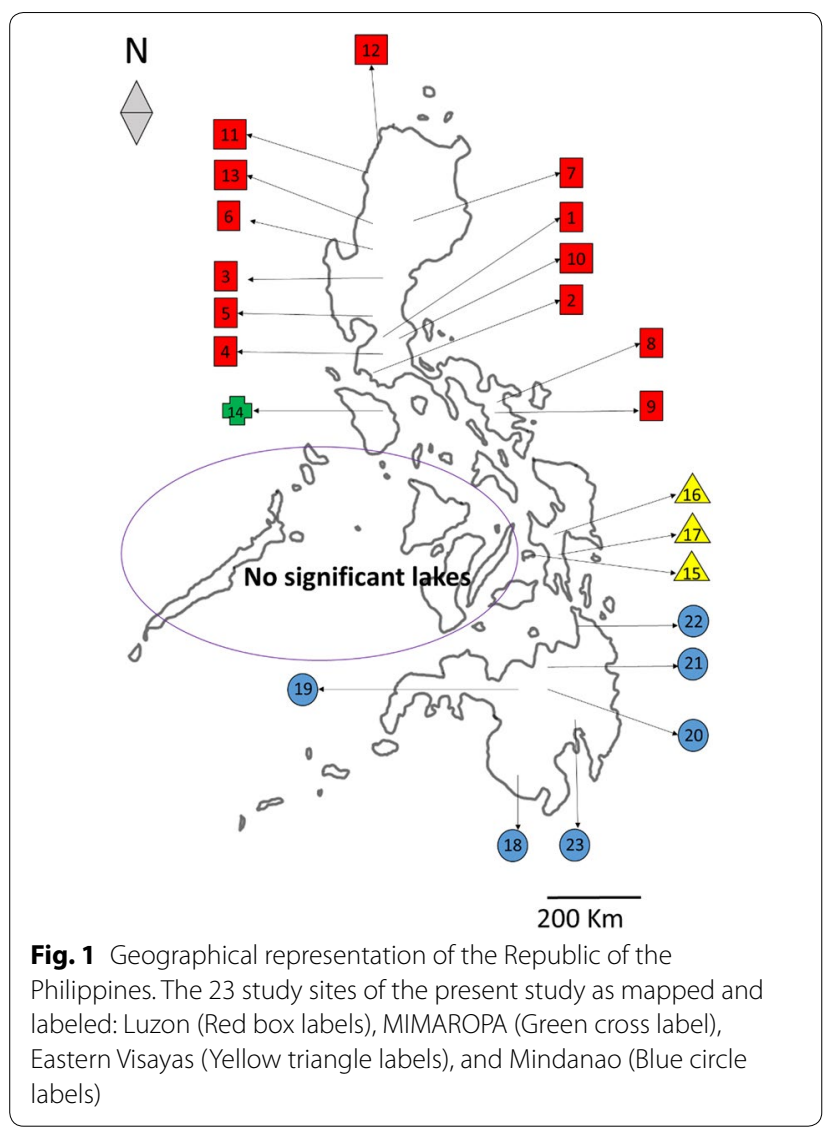

the $50 \mathrm{~mL}$ sterile polyethylene containers and suspended in $50 \mathrm{~mL}$ sterile distilled water. In the absence of aquatic plants, adherent biofilms (approximately $2 \mathrm{~g}$ wet weight) were scraped from rocks no more than $30 \mathrm{~cm}$ below the water surface. Samples were transported to the laboratory and processed within $48 \mathrm{~h}$ after collection. Each sample was vortexed for $1 \mathrm{~min}$ to dislodge adherent cells from any larger organic substances and debris to evenly distribute the solids throughout each sample matrix and left to stand for $5 \mathrm{~min}$ to settle heavier solids. The SW, $B W$, and SAB sample suspensions were each manually filtered through a $1.2 \mu \mathrm{m}$ pore size Glass microfiber filter (Whatman $^{\mathrm{TM}}$ ) fitted inside $50 \mathrm{~mL}$ plastic syringes. Glass microfiber filters were recovered and placed on sterile disposable polyethylene plates, where the filtered sediments were scraped using a sterile inoculating loop and $5 \mathrm{~mL}$ sterile distilled water as eluent. The $5 \mathrm{~mL}$ eluates were transferred to sterile test tubes and centrifuged at $1500 \mathrm{~g}$ for $15 \mathrm{~min}$ where $3 \mathrm{~mL}$ of the supernatants were discarded and the remaining $2 \mathrm{~mL}$ and pellet were mixed to form a suspension and stored in microcentrifuge tubes for smearing within $24 \mathrm{~h}$. From each pellet suspension, a $1 \mathrm{~cm}$-diameter smear $(25 \mu \mathrm{L})$ was prepared, fixed with absolute methanol, and stained. The traditional staining employed were Modified Kinyoun's (MK) and Modified Safranin Methylene Blue (SMB), while fluorescence techniques utilized were Auramine (Aura) and Direct Antibody Fluorescence Technique (IFT) (Waterborne Inc. USA). Each smear was examined under 200 oil immersion fields (OIF) and 200 high power fields (HPF) for traditional and fluorescence microscopy, respectively [31, 32]. Microscopic Cryptosporidium oocyst identification was compared with C. parvum positive controls (Waterborne Inc., USA) based on measurements and morphologic characteristics referenced from the CDC [33]. Theoretical approximates of oocyst counts per $50 \mathrm{~mL}$ sample matrix were extracted from the range of oocysts visualized in 200 microscopic fields per $1 \mathrm{~cm}$-diameter $(25 \mu \mathrm{L})$ smear area [32].

\section{Molecular analysis}

Molecular detection through Polymerase Chain Reaction (PCR) was performed on $1 \mathrm{~L}$ bulk SW samples from each sampling site $(n=29)$ to provide sufficient genetic material for DNA extraction. Each $1 \mathrm{~L}$ bulk SW sample was vacuum-filtered through a $47 \mathrm{~mm}$ diameter, $1.2 \mu \mathrm{m}$ pore size glass microfiber filter (Whatman ${ }^{\mathrm{TM}}$ ) using a simple Buchner funnel, and electric-operated diaphragm pump (Fisher Scientific Pte Ltd). The filtered material was harvested from the glass microfiber filter while still wet by eluting with sterile distilled water and gently scraped using a sterile scalpel blade. The eluted material was placed in sterile $10 \mathrm{~mL}$ test tubes and centrifuged at $1500 \mathrm{~g}$ for $15 \mathrm{~min}$ [34] after which the supernatant was discarded and the pellet was stored in $2 \mathrm{~mL}$ PCR tubes. DNA extraction was performed using the QIAamp ${ }^{\circledR}$ PowerFecal ${ }^{\circledR}$ Pro DNA Kit (Qiagen, Germany) with one cycle of freeze-thaw (FT) pretreatment performed on $500 \mu \mathrm{L}$ pellet suspension by overnight freezing in $-7^{\circ} \mathrm{C}$ and boiling in $100{ }^{\circ} \mathrm{C}$ digital dry bath (BIO-RAD) for 10 min. PCR was performed following previously published protocols [35] with modifications of using a nonnested protocol with primer set Cry18S-S2 (5'-GGTGAC TCATAACTTTACGG-3) and Cry18S-As2 (5'-ACGCTA TTGGAGCTGGAATTAC-3'). Amplicons were visualized by gel electrophoresis on a $1.5 \%$ agarose gel stained with ethidium bromide applied with 180 volts electricity for 15 min using PowerPac ${ }^{\text {TM }}$ Basic (BIO-RAD). Amplicons from PCR-positive samples were sent to a commercial sequencing company (Macrogen South Korea). Sequences were aligned using Clustal W of Bioedit with a careful visual inspection of gaps and ambiguous sequences and were deposited in GenBank. Phylogenetic and molecular evolutionary analysis was conducted using Mega version 7 which was based on the best tree model with bootstrap set at 1000 replicates [36]. 


\section{Results and discussion}

\section{Microscopic detection of Cryptosporidium oocysts}

A total of 179 environmental aquatic matrices were collected, which comprised of SW $(n=72)$, BW $(n=68)$, and SAB $(n=39)$ (Additional file: 2 and 3). Among the microscopy tests employed, IFT consistently provided the highest positivity with 59\% (17/29), 38\% (10/26), and $50 \%(10 / 20)$ detection in SW, BW, and SAB, respectively (Table 1). MK, SMB, and Aura also proved useful in terms of being cost-effective, but delivered lower detection rates. Cryptosporidium oocysts from environmental aquatic matrices were morphologically consistent with published descriptions and images of Cryptosporidium oocysts from the CDC and demonstrated consistent morphologic features when compared to C. parvum positive control (Fig. 2a to d). Under $1000 \times$ magnification of light microscopy (MK/SMB), Cryptosporidium oocysts from sample matrices were round, $4-6 \mu \mathrm{m}$ in diameter, and stained bright red against a blue background (Fig. 2e and f). IFT confirmation of Cryptosporidium oocysts under $400 \times$ magnification visualized round oocysts measuring 4-6 $\mu \mathrm{m}$ in diameter that fluoresced brightapple-green against a black background (Fig. 2h). In the present study, microscopic examination of $1 \mathrm{~cm}$-diameter smear area $(25 \mu \mathrm{L})$ under 200 microscopic fields using light microscopy (MK/SMB; 1000X magnification) and fluorescence microscopy (Aura/IFT; 400X magnification) mostly reported a range of 0-1 Cryptosporidium oocysts in $25 \mu \mathrm{L}$ pellet suspension (Additional file 3). This number of oocysts translates theoretically to oocyst counts of 0-2000 per $50 \mathrm{~mL}$. In the current study, the microscopic confirmation of Cryptosporidium oocysts with IFT [34] agrees with the 55\% detection in raw and finished waters in North-eastern Spain [37], with variations in results attributed to water qualities unique to each sampling site and types of aquatic matrices tested [38]. The microscopic detection and the theoretical approximate of $0-2000$ oocysts per $50 \mathrm{~mL}$ or $0-40,000$ oocysts per $1 \mathrm{~L}$ bulk SW sample suggest high contamination compared to lower estimates reported in Thailand [39], Australia [40], and Iran [41]. The higher oocyst count in the current study can be attributed to several factors. Methodologically, the direct filtration, elution, and pelleting of lowvolume $(50 \mathrm{~mL})$ aquatic matrices supposedly minimized the potential loss of oocysts if processed using multiple sequential steps $[16,34]$, while the standardized smear area of $1 \mathrm{~cm}$ diameter $(25 \mu \mathrm{L})$, systematic, and exhaustive microscopy (200 fields per $1 \mathrm{~cm}$-diameter smear area) aided in increased detection (Additional file 3: Table S3), where the results provided a clear picture of the distribution of Cryptosporidium spp. oocysts in environmental
Table 1 Summary of microscopic results of low-volume $(50 \mathrm{~mL})$ aquatic matrices

\begin{tabular}{|c|c|c|c|}
\hline \multirow[t]{2}{*}{ Sampling site $(n=29)$} & \multicolumn{3}{|c|}{ Microscopy and sample matrix } \\
\hline & SW & BW & SAB \\
\hline \multicolumn{4}{|l|}{ Luzon } \\
\hline S1 Laguna de bay & $1,3,4$ & 1,4 & - \\
\hline S2 Taal Lake & 3,4 & - & 3 \\
\hline S3 Pantabangan Lake & 3,4 & 4 & - \\
\hline S4.1 Sampaloc Lake & 3,4 & - & 3 \\
\hline S4.2 Bunot Lake & - & - & 3,4 \\
\hline S4.3 Palakpakin Lake & - & - & nc \\
\hline S4.4 Mojicap Lake & - & 3,4 & - \\
\hline S4.5 Yambo Lake & - & - & - \\
\hline S4.6 Pandin Lake & - & - & nc \\
\hline S4.7 Kalibato Lake & 3,4 & - & - \\
\hline S5 Ipo water reservoir & 4 & - & nc \\
\hline S6 Magat water reservoir & $1,3,4$ & $1,2,3,4$ & nc \\
\hline S7 San Roque water reservoir & 1,3 & $1,2,3,4$ & $\mathrm{nc}$ \\
\hline S8 Buhi Lake & - & 4 & 1,4 \\
\hline s9 Bato Lake & - & - & - \\
\hline S10 Cavinti/Lumot Lake & - & $\mathrm{Nc}$ & nc \\
\hline S11 West Pudoc fish ponds & 4 & 4 & 4 \\
\hline S12 Paoay Lake & 4 & 1 & $\mathrm{nc}$ \\
\hline S13 Ambuklao water reservoir & 3,4 & $\mathrm{Nc}$ & $1,3,4$ \\
\hline \multicolumn{4}{|l|}{ Mimaropa } \\
\hline S14 Naujan Lake & 4 & 4 & $1,3,4$ \\
\hline \multicolumn{4}{|l|}{ Visayas } \\
\hline S15 Sakanaw Lake & 4 & - & - \\
\hline S16 Danao Lake & 1 & 1,3 & - \\
\hline S17 Bito Lake & - & $1,2,3$ & $1,3,4$ \\
\hline \multicolumn{4}{|l|}{ Mindanao } \\
\hline S18 Sebu Lake & 1,4 & 1,4 & 4 \\
\hline S19 Pulangi water reservoir & 4 & - & nc \\
\hline S20 Bukidnon farm irrigation & 4 & $\mathrm{nc}$ & nc \\
\hline S21 Lanao Lake & $1,3,4$ & - & $2,3,4$ \\
\hline S22 Mainit Lake & $1,3,4$ & 4 & 4 \\
\hline S23 Tagunay River & 3 & - & 4 \\
\hline Matrix prevalence & $69 \%(20 / 29)$ & $50 \%(13 / 26)$ & $60 \%(12 / 20)$ \\
\hline \multicolumn{4}{|l|}{ Rates of detection } \\
\hline 1 & $24 \%(7 / 29)$ & $27 \%(7 / 26)$ & $20 \%(4 / 20)$ \\
\hline 2 & $0 \%(0 / 29)$ & $12 \%(3 / 26)$ & $5 \%(1 / 20)$ \\
\hline 3 & $38 \%(11 / 29)$ & $19 \%(5 / 26)$ & $35 \%(7 / 20)$ \\
\hline 4 & $59 \%(17 / 29)$ & $38 \%(10 / 26)$ & $50 \%(10 / 20)$ \\
\hline
\end{tabular}

SW, surface water; BW, sediments with bottom water; SAB, substrate-associated biofilms; 1 Modified Kinyoun (MK); 2 Safranin Methylene Blue (SMB); 3 Auramine (Aura); 4 Immunofluorescence (IFT); nc, no sample collected; - negative

Details of sampling areas such as date and time of collection, location, coordinates, temperature, rain, surface area, and elevation can be found in Additional file 1

A detailed breakdown of microscopy panel results per sampling point can be found in Additional files 2 and 3 


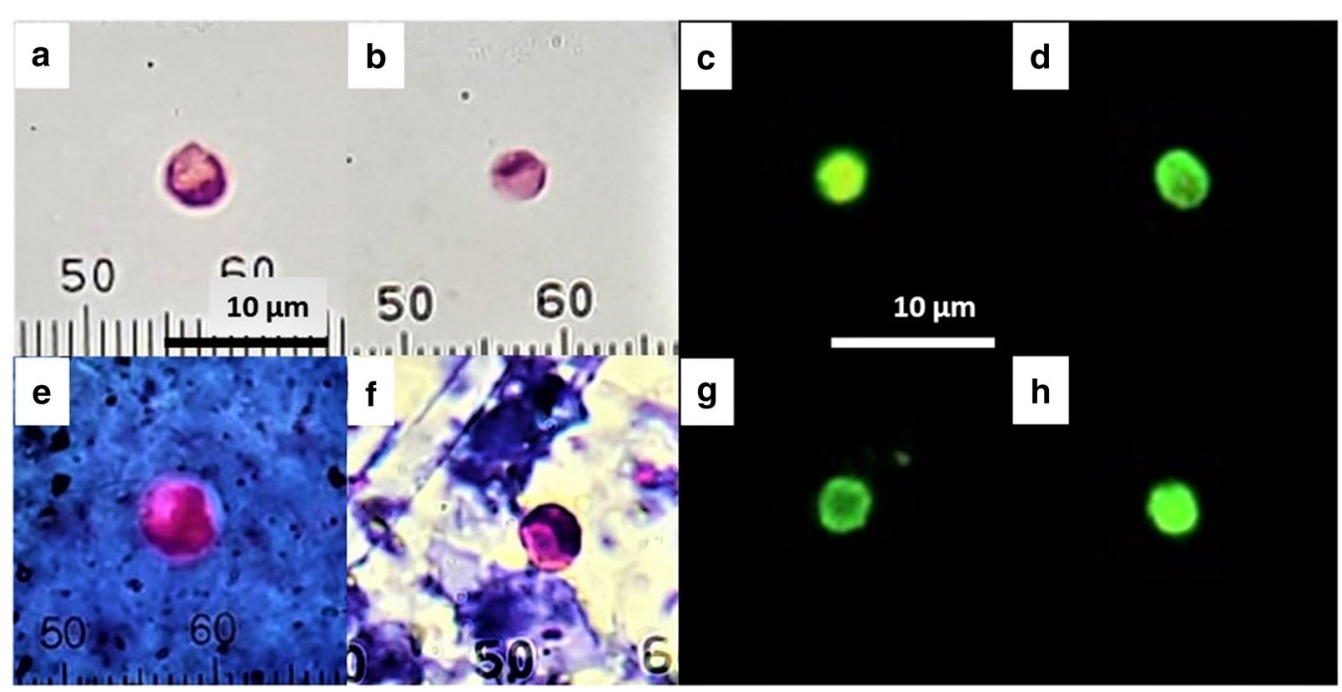

Fig. 2 C. parvum positive control and Cryptosporidium spp. oocysts from environmental aquatic matrices. a-d positive control; a C. parvum (MK); b C. parvum (SMB); c C. parvum (Aura); d C. parvum (IFT); e S1 SW (MK); f S6 BW (SMB); $\mathbf{g}$ S13 SAB (Aura); h S19 SW (IFT); a, b, e, and f $1000 \mathrm{X}$ magnification; $\mathbf{c}, \mathbf{d}, \mathbf{g}$, and $\mathbf{h} 400 \times$ magnification; scale bars $=10 \mu \mathrm{m}$

freshwater systems all over the country. Matrix wise, the analysis of raw/untreated water potentially offers higher oocysts contamination compared to treated water [42]. However, the actual density of Cryptosporidium oocysts in some of the investigated SW samples was suspected to be below the theoretical estimates and Cryptosporidium DNA was successfully amplified only in six out of the 29 bulk SW samples (Table 2). The theoretical estimates require further verification also through the performance of recovery efficiency in the future. Theoretical estimates should not be taken as absolute counts, since the oocysts are unevenly dispersed in water or they may be associated with substrates [9, 31, 32, 43]. In addition, different concentration methods offer varying degrees of recovery efficiencies [37, 44]. It should be noted that the lowvolume $(50 \mathrm{~mL})$ sampling strategy models the theoretical amount of water that could be accidentally ingested or inhaled by an individual during anthropogenic activities in water systems. This defines functional data on the minimum volume of environmental water that can potentially harbor and transmit Cryptosporidium oocysts to humans and animals [32].

Table 2 Molecular detection of Cryptosporidium spp. in $\mathbf{1}$ L bulk surface water samples

\begin{tabular}{|c|c|c|c|c|c|}
\hline \multirow[t]{2}{*}{ Site } & \multirow[t]{2}{*}{ Molecular results } & \multirow[t]{2}{*}{ GenBank Accession no. } & \multicolumn{3}{|c|}{ Cryptosporidium prevalence } \\
\hline & & & Island & Sampling site & Study site \\
\hline Luzon & & & $15 \%(2 / 13)$ & $21 \%(6 / 29)$ & $26 \%(6 / 23)$ \\
\hline S4.5 Yambo Lake & Cryptosporidium parvum & MT221250 & & & \\
\hline S13 Ambuklao water reservoir & Cryptosporidium hominis & MT221550 & & & \\
\hline Visayas & & & $33 \%(1 / 3)$ & & \\
\hline S17 Bito Lake & Cryptosporidium spp. & MT234345 & & & \\
\hline Mindanao & & & $50 \%(3 / 6)$ & & \\
\hline S19 Pulangi water reservoir & Cryptosporidium parvum & (MT219974) & & & \\
\hline S21 Lanao Lake & Cryptosporidium hominis & (MT221440) & & & \\
\hline \multirow[t]{5}{*}{ S23 Tagunay River } & Cryptosporidium hominis & (MT221442) & & & \\
\hline & & & \multicolumn{3}{|c|}{ Cryptosporidium spp. sampling site prevalence } \\
\hline & & & C. parvum & & $7 \%(2 / 29)$ \\
\hline & & & C.hominis & & $10 \%(3 / 29)$ \\
\hline & & & Cryptosporidium spp. & & $3 \%(1 / 29)$ \\
\hline
\end{tabular}




\section{Molecular identification of Cryptosporidium species}

Molecular analysis of $1 \mathrm{~L}$ bulk SW samples confirmed six sampling sites were contaminated with C. parvum, C. hominis, and other Cryptosporidium spp. (Table 2 and Fig. 3). Luzon sampling sites had a recorded Cryptosporidium prevalence of $15 \%(2 / 13)$ with $C$. parvum in Yambo Lake and C. hominis in Ambuklao water reservoir. Visayas sampling sites presented with $33 \%$ (1/3) prevalence, with Bito Lake isolate registered under Cryptosporidium species. Mindanao sampling sites recorded a $50 \%(3 / 6)$ prevalence with $C$. parvum in Pulangi water reservoir, $C$. hominis in Lanao Lake, and another $C$. hominis isolate in Tagunay River. On a nationwide scale, the molecular prevalence of Cryptosporidium was in total at $21 \%(6 / 29)$ in sampling sites where the differential identification of C. parvum, C. hominis, and Cryptosporidium spp. was at $7 \%(2 / 29), 10 \%(3 / 29)$, and $3 \%(1 / 29)$, respectively (Table 1). The sequences of the environmental aquatic isolates were deposited in GenBank under the accession numbers MT221250, MT221550, MT234345, MT219974, MT221440, and MT221442 with reference sequences listed in Table 3. The molecular prevalence of Cryptosporidium from our Philippine study sites (26\%) agrees with reports in water supplies in Turkey (27\%) [21]. In addition, the differential prevalence of C. parvum in the present study (7\%) is also similar to the molecular confirmation of $C$. parvum in a multi-use catchment in South Australia [40]. The amplification of the $18 \mathrm{~S}$ rRNA locus using PCR offered lower cost as compared to RT-PCR or qPCR assays with the non-nested protocol responsible for reducing 5-6 h of run-time per batch of 12-15 samples. Furthermore, the diagnostic sensitivity (96.9\%) and specificity (98.4\%) of $18 \mathrm{~S}$ rRNA PCR for Cryptosporidium is high, with an analytical sensitivity of 1-10 oocysts per reaction [45]. The applied non-nested protocol did not seem to affect the PCR sensitivity as it enabled the detection of C. parvum (GenBank accession number MT221250) in S4.5 Yambo Lake even if it was negative for all four microscopy methods in all three $50 \mathrm{~mL}$ counterparts (Tables 1 and 2). Microscopy positive but PCR-negative samples may be attributed to the density and characteristics of suspended solids (Additional file 4) and abundant PCR inhibitors because of high-industrially polluted environmental study sites [10, $21,37,43]$. A low ratio of PCR-positive results was also reported in Finland [46], France [47], Hungary [48], and Spain [49] with a case of PCR-negative results in all 20 study sites in North-eastern Spain despite IFT detection of Cryptosporidium [37].

\section{Water quality assessment strategies and multi-spatial distribution of Cryptosporidium}

The detection of Cryptosporidium oocysts requires adjusting sampling and processing details to fit specific

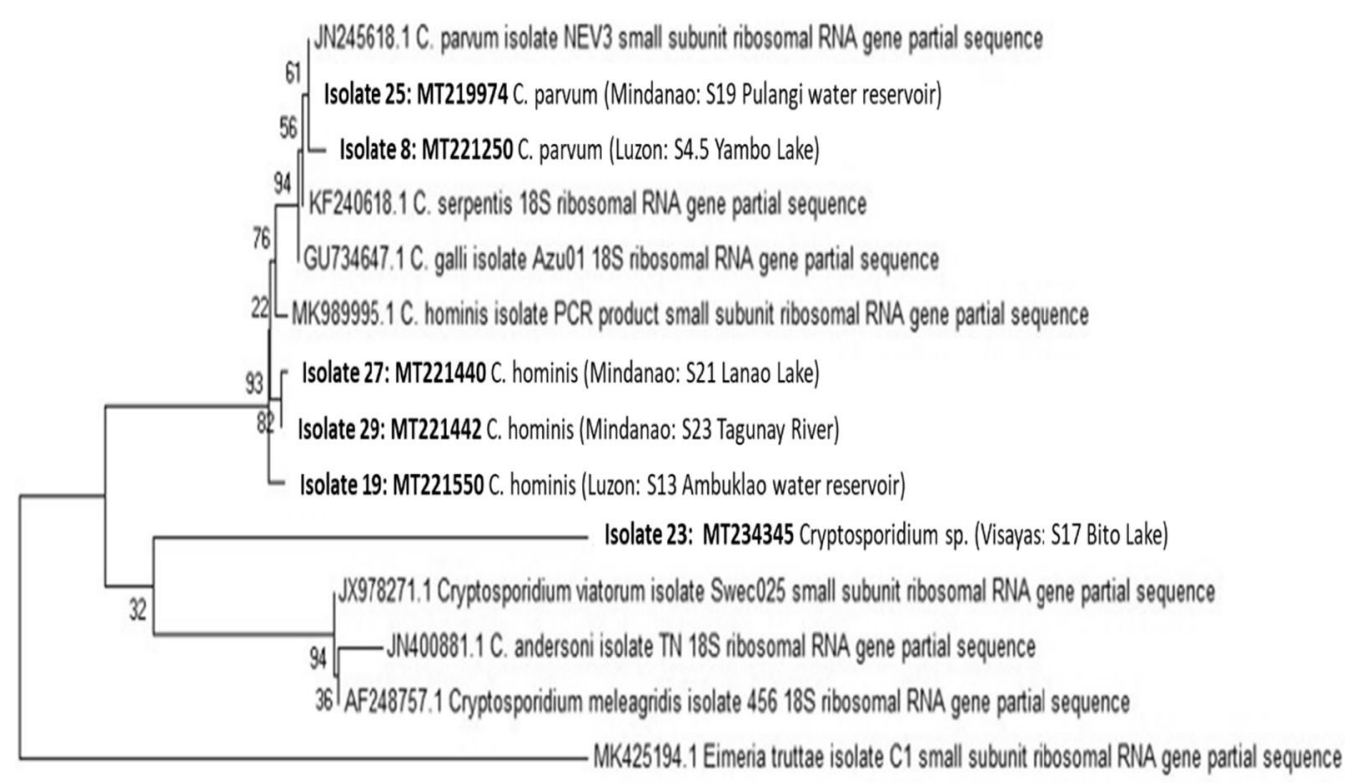

0.10

Fig. 3 Molecular phylogenetic analysis by Maximum-Likelihood method. Phylogenetic tree of isolates 8, 25, 27, 29, 19, and 23 with reference sequences of different human and animal Cryptosporidium species with Eimeria used as the outgroup. The evolutionary distances between sequences were calculated by the Kimura two-parameter model. Values on the branches are percent bootstrapping value using 1000 replicates 
Table 3 Reference sequences used in the present study

\begin{tabular}{|c|c|c|}
\hline Reference sequences & Source/Country & GenBank accession no. \\
\hline \multicolumn{3}{|l|}{ Human pathogens representative } \\
\hline C. parvum isolate NEV3 ssrRNA gene partial sequence & Diarrheic calf feces/Turkey & $J N 245618.1$ \\
\hline $\begin{array}{l}\text { C. hominis isolate PCR product ssrRNA gene partial } \\
\text { sequence }\end{array}$ & Freshwater sponge/Philippines & MK989995.1 \\
\hline C. viatorum isolate Swec025 ssrRNA gene partial sequence & Humans/Kenya & JX978271.1 \\
\hline C. meleagridis isolate $45618 \mathrm{~S}$ rRNA gene partial sequence & Human feces/ ${ }^{a}$ & AF248757 \\
\hline \multicolumn{3}{|l|}{ Mammalian representative } \\
\hline $\begin{array}{l}\text { C. andersoni isolate TN } 18 \mathrm{~S} \text { ribosomal RNA gene partial } \\
\text { sequence }\end{array}$ & Calf/India & JN400881.1 \\
\hline \multicolumn{3}{|l|}{ Avian representative } \\
\hline C. galli isolate Azu01 18S rRNA gene partial sequence & Cyanocompsa brissonii (ultramarine grosbeak), feces/Brazil & GU734647.1 \\
\hline \multicolumn{3}{|l|}{ Reptilian representative } \\
\hline C. serpentis $18 \mathrm{~S}$ rRNA gene partial sequence & Pantherophis guttatus (corn snake), feces/Brazil & KF240618.1 \\
\hline \multicolumn{3}{|l|}{ Outgroup } \\
\hline $\begin{array}{l}\text { Eimeria truttae isolate C1 small subunit rRNA gene partial } \\
\text { sequence }\end{array}$ & $\begin{array}{l}\text { Salmo trutta (Brown trout), pyloric caeca and intestinal } \\
\text { content/Spain }\end{array}$ & MK425194.1 \\
\hline
\end{tabular}

a Not declared

water qualities. The summary of microscopy results per sampling site revealed that the spatial distribution of Cryptosporidium oocysts in aquatic matrices was highest in SW at 69\% (20/29) and lowest in BW at 50\% (13/26) (Table 1). Cryptosporidium oocysts exist among other naturally occurring particles in various water samples including sediments, sewage water, surface, and groundwater, even in chlorinated swimming pools and hot springs [9, 24, 50-52]. However, investigations delving into interactions with biofilms are limited $(14,57)$. Seasonal changes influencing biofilm profile and retention of Cryptosporidium oocysts have been described [53, 54]; water depth influences biofilm thickness and other biologic masses like freshwater sponges may facilitate protection against UV radiation, although largely known as requiring an animal cell for its complex biological progression [31, 32, 55, 56], Cryptosporidium excystation and developmental stages have been demonstrated in in-vitro Pseudomonas aeruginosa biofilms [14] and even in in-vitro axenic cultures [57]. It is, therefore, of great interest, to further expand Cryptosporidium investigations in biofilms in aquatic and fluid systems.

Low-volume $(50 \mathrm{~mL})$ water sampling for the detection of Cryptosporidium was reported in two previous studies that demonstrated its utility in PCR analysis in a river sample in China [43] and the first MK/PCR detection of $C$. hominis in a freshwater sponge [31]. Low-volume sampling provided the advantages of ease of collection, transport, multiple matrix sampling, large sampling site coverage, reproducibility, adjusted density of suspended solids, and significantly lower test cost, and enables large-scale surveys, as was the case for the present study. Multiple matrix sampling proved its benefits in increasing the detection of Cryptosporidium oocysts and decreased occasions of declaring false-negative microscopy results in sampling sites where positivity in SW agreed with either BW and/or SAB results. More importantly, on some occasions, negative results in SW proved positive in BW and/or SAB (Table 1).

\section{Water contamination with Cryptosporidium in a climate, health, and regulatory framework}

The Philippine archipelago is located in Southeast Asia, a region of the globe that is highly susceptible to the influences of climate change and water crises [26]. Research on the health effects of climate change is estimated to be only half of that in other areas impacted by the same like agriculture and forestry. To date, poor research output on the effects of climate change to health somewhat infers that most health scientists are still unaware of the present and impending mortality and morbidity this iceberg of a problem truly poses [28]. According to the Institute of Health Metrics and Evaluation (IHME), Global Burden of Disease study in 2017, contaminated water sources were the leading risk factor for child deaths due to diarrhea [58]. Globally, climate models predict precipitation to become more intensive over most land areas, where North America, Europe, and Asia may experience the greatest increase in heavy downpours [59]. A study on the availability of freshwater that can be used for drinking and growing food has shown that two of three people on earth live in areas, where water consumption is twice as great as availability [60]. The El Niño phenomenon has and continually affects the growth of crops and the 
availability of clean drinking water in the Philippines [61, 62]. This represents an unknown situation on the compounded effects of altered patterns in human consumption, levels of nutritional intake and dehydration, as well as the development of non-transmissible and waterborne diseases in relation to climate change.

As early as 2001, heavier precipitation events have influenced the increasing reports of outbreaks of waterborne diseases including hepatitis A, cholera, E. coli, leptospirosis, and cryptosporidiosis due to increasing population, urban landscapes, and overflow of sewer systems [63]. Similarly, the absence of sewer systems promotes waterborne disease outbreaks and so does the lack of rain and scarcity of freshwater supply [64]. In the Philippines, even its metropolis is not well equipped with sewer systems connected to water treatment facilities; rather, open sewer systems are the norm which contributes to the continuous contamination and deterioration of environmental freshwater systems by way of pollution with domestic and industrial wastes [65]. Ironically, these polluted freshwater resources are, at present, the primary sites utilized for aquaculture, irrigation of agricultural lands, human, and veterinary activities which may play a significant role in the cycling of waterborne diseases to humans, animals, and the environment [32].

To date, limited efforts have been exerted in Cryptosporidium research in unraveling its prevalence in freshwater resources in the Philippines; making concepts relative to Cryptosporidium neglected or relatively unknown among local water quality analysts and healthcare practitioners. This lack of information is a gap in understanding Cryptosporidium and may be responsible for non-diagnosis and/or misdiagnosis in healthcare, which can be evidenced by the last report of Cryptosporidium diagnosis in cancer patients in the Philippines 15 years ago [66]. Non-inclusion in local quality standards for water potability leads to an accumulated underreported incidence at a nationwide scale.

The current study provides the first molecular epidemiologic data of Cryptosporidium from the largest lakes and major water reservoirs in the country, where four major water reservoirs were confirmed to be contaminated with human pathogenic species of Cryptosporidium namely: Ambuklao (C. hominis), Pulangi (C. parvum), Lanao lake (C. hominis), and Tagunay river (C. hominis). Two lakes that are major sources of livelihood and aquaculture were also found to be contaminated with C. parvum (Yambo Lake) and Cryptosporidium spp. (Bito Lake). The immunocompromised population is at high risk of contracting Cryptosporidium infection [67]. Cryptosporidium has been reported from children undergoing chemotherapy [68], immunodeficiency, and organ transplant patients in Iran [69]. Cryptosporidiosis in pediatric liver transplants recipients has been reported to cause significant complications [70]. Malaysia reported C. parvum and C. hominis genotypes from HIV patients [71]. Poland reported a higher frequency of Cryptosporidium infections from colorectal cancer patients [72]. A Southeast Asian systematic review and meta-analysis revealed a significant relationship between cryptosporidiosis and the risk of chronic diarrhea in people with HIV [67]. Although case reports from the immunocompetent population are rare, it should be speculated whether underlying conditions may contribute to susceptibility to Cryptosporidium infection or trigger the progression of the same as a case in Poland reported C. meleagridis from an immunocompetent patient with adenocarcinoma [73]. Furthermore, a 2019 survey in the Czech Republic reported a widespread and chronic low-level exposure from 301 blood donors [74]. The molecular confirmation of Cryptosporidium in freshwater systems in the Philippines suggests unknown effects contributed by chronic low-level exposures, the potential for human infection, or even worse, outbreak scenarios following the ingestion of contaminated water due to the presence of human pathogenic species C. parvum and C. hominis [75-77]. In Israel, a 14 year study consisting of 522 Cryptosporidium cases submitted to its government the inclusion of Cryptosporidium among the mandatory notifiable diseases for timely detection of outbreaks [78].

To date, there is no policy in the Philippines on the detection and monitoring of Cryptosporidium and other relevant waterborne protozoan pathogens (WBPP) in waters for human use. The results of the present study warrant the inclusion of Cryptosporidium and other WBPP in water quality assessment of freshwater resources and drinking water. The formulation of initiatives for the simultaneous testing of SW, BW, and SAB will provide important data in the multi-spatial distribution of Cryptosporidium oocysts within aquatic systems, along with increased chances of detection [32].

The data conceived from the present study are the first national report on the microscopic and molecular prevalence of Cryptosporidium in environmental aquatic matrices. This can stimulate further research, the development of both private and governmental initiatives, and sustainable solutions in monitoring and safeguarding the quality of environmental freshwater and drinking water resources. A climate and health approach is necessary for the comprehension, prevention, mitigation, and management of Cryptosporidium contamination and infection.

\section{Conclusions}

Microscopy results demonstrated an abundance of Cryptosporidium oocysts in surface water, sediments, and substrate-associated biofilms from environmental 
freshwater systems. The results of the present study provided the first national molecular epidemiologic data on the distribution of Cryptosporidium parvum and $C$. hominis in the Republic of the Philippines. Employing low-volume $(50 \mathrm{~mL}$ and $1 \mathrm{~L})$, multiple matrices, and multiple sampling area strategies is a low-cost, user-friendly, sustainable, and reproducible method of detecting Cryptosporidium from environmental aquatic matrices, and can be performed even in resource-limited settings. A standardized and systematic microscopic examination for the optimal detection of Cryptosporidium oocysts from low-volume environmental aquatic matrices complemented with $18 \mathrm{~S}$ rRNA PCR and sequencing seems to be a successful strategy. The climate and health framework calls for the formulation of a national policy in the inclusion of Cryptosporidium and other waterborne protozoan pathogens in water quality assessment and monitoring. It would be interesting to have samples from different seasons in the year. This initiative is indispensable in preventing and mitigating unforeseen effects of chronic low-level exposures, cases of infections, and potential outbreak scenarios.

\section{Supplementary information}

Supplementary information accompanies this paper at https://doi. org/10.1186/s12302-020-00410-w.

Additional file 1: Consolidated details of Study sites, sampling sites, and sampling points in the Philippines.

Additional file 2: Cryptosporidium spp. low-volume microscopy panel and bulk water $P C R$ results.

Additional file 3: Raw data on Cryptosporidium spp. oocyst counts in 200 microscopic fields per $1 \mathrm{~cm}$ diameter $(25 \mu \mathrm{L})$ smear.

Additional file 4: Filtered sediments of $1 \mathrm{~L}$ bulk water samples from sampling sites. Filtration of low-volume $(1 \mathrm{~L})$ bulk water with $1.2 \mu \mathrm{m}$ pore size glass microfiber filter is efficient in recovering dispersed sediments from surface water samples and can be used for high turbidity aquatic matrices by simply changing the filter once full. Different sampling sites show different density and physical characteristics of suspended solids.

\section{Abbreviations}

MIMAROPA: Mindoro, Marinduque, Romblon, and Palawan; MASL: Meters above sea level; SW: Surface water; BW: Sediments; SAB: Substrate-associated biofilms; MK: Modified Kinyoun's staining; SMB: Modified Safranin Methylene Blue staining; Aura: Auramine staining; IFT: Immunofluorescence test; OIF: Oil immersion field; HPF: High power field; CDC: Center for Disease Control and Prevention; PCR: Polymerase chain reaction; FT: Freeze thaw; ssrRNA: Small subunit ribosomal Ribonucleic acid; UV: Ultraviolet; IHME: Institute of Health Metrics and Evaluation; HIV: Human immunodeficiency virus; WBPP: Waterborne protozoan pathogens.

\section{Acknowledgements}

Deep gratitude is extended to Joseph Dionisio, Romel Solomon, Virgilio Bitagcul, Noel Cajuday, Maria Lourdes Policarpio, Ivy Timogtimog, and Ariel Lopez of the Department of Medical Technology, Far Eastern University-Manila for the laboratory logistics; Harry Esmaya of Howell Medical supplies for the fluorescence microscopy facility; and Dr. Henry H. Stibbs, Angela Faust, and Molly Rowe of Waterborne Inc. for the comprehensive IFT kit.

\section{Authors' contributions}

FRM, GDM, JT, and PK designed the experimental set-up. FRM and GDM were responsible for sample collection. VS, MK, and JT were responsible for supervision and funding. PK was responsible for supervision and expert analysis. FRM and GDM performed the analysis. FRM and PK drafted the manuscript. All authors were responsible for the interpretation of data and review of the manuscript. All authors read and approved the final manuscript.

\section{Funding}

This work was supported by The Walailak University Graduate Studies Research Fund, Thailand [Contract No. 24/2562].

\section{Availability of data and materials}

Not applicable.

Ethics and consent to participate

Not applicable.

\section{Consent for publication}

Not applicable.

\section{Competing interests}

The authors declare that they have no competing interests.

\section{Author details}

${ }_{1}^{1}$ Biomedical Sciences Program, School of Allied Health Sciences, Walailak University, Nakhon, Si Thammarat 80160, Thailand. ${ }^{2}$ Department of Medical Technology, Institute of Arts and Sciences, Far Eastern University, Manila 1015, Philippines. ${ }^{3}$ University of Cologne, Faculty of Medicine and University Hospital Cologne, Cologne, Germany. ${ }^{4}$ Department of Basic and Clinical Sciences, University of Nicosia Medical School, Nicosia 2408, Cyprus.

Received: 15 June 2020 Accepted: 18 September 2020

Published online: 25 September 2020

\section{References}

1. Checkley W, White AC Jr, Jaganath D, Arrowood MJ, Chalmers RM, Chen XM, Fayer R, Griffiths JK, Guerrant RL, Hedstrom L, Huston CD, Kotloff KL, Kang G, Mead JR, Miller M, Petri WA Jr, Priest JW, Roos DS, Striepen B, Thompson RC, Ward HD, Van Voorhis WA, Xiao L, Zhu G, Houpt ER (2015) A review of the global burden, novel diagnostics, therapeutics, and vaccine targets for Cryptosporidium. Lancet Infect Dis 15(1):85-94. https:// doi.org/10.1016/S1473-3099(14)70772-8

2. Savioli L, Smith H, Thompson A (2006) Giardia and Cryptosporidium join the 'neglected diseases initiative'. Trends Parasitol 22:203-208. https://doi. org/10.1016/j.pt.2006.02.015

3. Okhuysen PC, Chappell CL, Crabb JH, Sterling CR, DuPont HL (1999) Virulence of three distinct Cryptosporidium parvum isolates for healthy adults. J Infect Dis 180(4):1275-1281. https://doi.org/10.1086/315033

4. Steiner TS, Thielman NM, Guerrant RL (1997) Protozoal agents: what are the dangers for the public water supply? Annu Rev Med 48:329-340. https://doi.org/10.1146/annurev.med.48.1.329

5. Baldursson S, Karanis P (2011) Waterborne transmission of protozoan parasites: review of worldwide outbreaks — an update 2004-2010. Water Res 45(20):6603-6614. https://doi.org/10.1016/j.watres.2011.10.013

6. Efstratiou A, Ongerth JE, Karanis P (2017) Waterborne transmission of protozoan parasites: review of worldwide outbreaks — an update 2011-2016. Water Res 114:14-22. https://doi.org/10.1016/j.watres.2017.01.036

7. Giglio GL, Sabogal-Paz LP (2018) Performance comparison of three methods for detection of Giardia spp. cysts and Cryptosporidium spp. oocysts in drinking-water treatment sludge. Environ Monit Assess 190(11):686. https://doi.org/10.1007/s10661-018-7057-9

8. Ladeia WA, Martins FDC, Silva CFRE, Freire RL (2018) Molecular surveillance of Cryptosporidium and Giardia duodenalis in sludge and spent filter backwash water of a treatment plant. J Water Health 16(5):857-860. https ://doi.org/10.2166/wh.2018.040

9. Kong Y, Lu P, Yuan T, Niu J, Li Z, Yang B (2017) Cryptosporidium contamination and attributed risks in Yunlong Lake in Xuzhou, China. Can J Infect Dis Med Microbio. https://doi.org/10.1155/2017/4819594 
10. Strathmann M, Horskott M, Koch C, Gayer U, Wingender J (2016) The River Ruhr — an Urban river under particular interest for recreational use and as a raw water source for drinking water: The Collaborative Research Project "Safe Ruhr" —microbiological Aspects. Int J Hyg Environ Health 219(7):643-661. https://doi.org/10.1016/j.ijheh.2016.07.005

11. Declerck P, Behets J, van Hoef V, Ollevier F (2007) Detection of Legionella spp. and some of their amoeba hosts in floating biofilms from anthropogenic and natural aquatic environments. Water Res 41(14):3159-3167. https://doi.org/10.1016/j.watres.2007.04.011

12. Preston TM, Richards H, Wotton RS (2001) Locomotion and feeding of Acanthamoeba at the water-air interface of ponds. FEMS Microbiol Lett 194(2):143-147

13. Flemming HC, Wingender J, Szewzyk U, Steinberg P, Rice SA, Kjelleberg $S$ (2016) Biofilms: an emergent form of bacterial life. Nat Rev Microbiol 14(9):563-575

14. Koh W, Thompson A, Edwards H, Monis P, Clode PL (2014) Extracellular excystation and development of Cryptosporidium: tracing the fate of oocysts within Pseudomonas aquatic biofilm systems. BMC Microbiol 14:281. https://doi.org/10.1186/s12866-014-0281-8

15. Wingender J, Flemming HC (2011) Biofilms in drinking water and their role as reservoir for pathogens. Int J Hyg Environ Health 6:417-423. https ://doi.org/10.1016/j.ijheh.2011.05.009

16. Efstratiou A, Ongerth J, Karanis P (2017) Evolution of monitoring for Giardia and Cryptosporidium in water. Water Res 123:96-112. https://doi. org/10.1016/j.watres.2017.06.042

17. Karanis P, Shoeden D, Setiz HM (1998) Distribution and removal of Giardia and Cryptosporidium in water supplies in Germany. Water Sci Technol 37:9-18

18. Gallas-Lindemann C, Sotiriadou I, Plutzer J, Noack MJ, Mahmoudi MR, Karanis P (2016) Giardia and Cryptosporidium spp. dissemination during wastewater treatment and comparative detection via immunofluorescence assay (IFA), nested polymerase chain reaction (nested PCR) and loop mediated isothermal amplification (LAMP). Acta Trop 158:43-51. https://doi.org/10.1016/j.actatropica.2016.02.005

19. Karanis P, Sotiriadou I, Kartashev V, Kourenti C, Tsvetkova N, Stojanova K (2006) Occurrence of Giardia and Cryptosporidium in water supplies of Russia and Bulgaria. Environ Res 102(3):260-271. https://doi. org/10.1016/j.envres.2006.05.005

20. Ma L, Zhang X, Jian Y, Li X, Wang G, Hu Y, Karanis P (2019) Detection of Cryptosporidium and Giardia in the slaughterhouse, sewage and river waters of the Qinghai Tibetan plateau area (QTPA). China. Parasitol Res 118(7):2041-2051. https://doi.org/10.1007/s00436-019-06330-w

21. Tsushima Y, Karanis P, Kamada T, Nagasawa H, Xuan X, Igarashi I, Fujisaki K, Takahashi E, Mikami T (2001) Detection of Cryptosporidium parvum oocysts in environmental water in Hokkaido, Japan. J Vet Med Sci 63(3):233-236. https://doi.org/10.1292/jvms.63.233

22. Tsushima Y, Karanis P, Kamada T, Xuan X, Makala LH, Tohya Y, Akashi H, Nagasawa $H$ (2003) Viability and infectivity of Cryptosporidium parvum oocysts detected in river water in Hokkaido, Japan. J Vet Med Sci 65(5):585-589. https://doi.org/10.1292/jvms.65.585

23. Tsushima Y, Karanis $P$, Kamada T, Makala L, Xuan X, Tohya Y, Akashi H, Nagasawa $H$ (2003) Seasonal change in the number of Cryptosporidium parvum oocysts in water samples from the rivers in Hokkaido, Japan, detected by the ferric sulfate flocculation method. J Vet Med Sci 65(1):121-123. https://doi.org/10.1292/jvms.65.121

24. Karanis $P$ (2018) The truth about in vitro culture of Cryptosporidium species. Parasitol 145(7):855-864. https://doi.org/10.1017/S00311820170019 37

25. WHO, Drinking water Key facts. 2018. Retrieved from: https://www.who, int/news-room/fact-sheets/detail/drinking-water

26. Leaf A (1989) Potential health effects of global climatic and environmental changes. N Engl J Med 321(23):1577-1583. https://doi.org/10.1056/ NEJM198912073212305

27. Sankoh O, Byass P (2012) The INDEPTH Network: filling vital gaps in global epidemiology. Int J Epidemiol 41(3):579-588. https://doi.org/10.1093/ije/ dys081

28. Verner G, Schutte S, Knop J, Sankoh O, Sauerborn R (2016) Health in climate change research from 1990 to 2014: positive trend, but still underperforming. Glob Health Action. 9:30723. https://doi.org/10.3402/ gha.v9.30723
29. Masangkay F, Milanez G, Chua N, Angulo F, Aquino P, Calucin D, Urtal $G$ (2016) Water-borne coccidians in Philippine water sheds: a national inceptive study. Asian J Biol Life Sci 5(2):112-119

30. Masangkay F (2019) Increased detection of Cryptosporidium and Cyclospora spp. oocysts in a major Philippine watershed following rainfall events. Asian J Biol Life Sci 8(3):111-116. https://doi.org/10.5530/ajbls 2019.8.18

31. Masangkay FR, Milanez GD, Tsiami A, Somsak V, Kotepui M, Tangpong J, Karanis P (2020) First report of Cryptosporidium hominis in a freshwater sponge. Sci Total Environ 700:134447. https://doi.org/10.1016/j.scito tenv.2019.134447

32. Masangkay FR, Milanez GD, Tsiami A, Hapan FZ, Somsak V, Kotepui M, Tangpong J, Karanis P (2020) Waterborne protozoan pathogens in environmental aquatic biofilms: implications for water quality assessment strategies. Environ Pollut 259:113903. https://doi.org/10.1016/j.envpo I.2019.113903

33. Center for Disease Control (CDC) DPDx Cryptosporidiosis. https://www. cdc.gov/dpdx/cryptosporidiosis/index.html. Accessed 1 March 2020

34. US EPA (2005) Method 1623: Cryptosporidium and Giardia in Water by Filtration/IMS/FA (PDF), December 2005 Update (EPA 821-R-05-002). Office of Water 4603. U.S. Environmental Protection Agency, Washington. http:// www.epa.gov/microbes/1623de05.pdf

35. Bairami Kuzehkanan A, Rezaeian M, Zeraati H, Mohebali M, Meamar AR, Babaei Z, Kashi L, Heydarnezhadi M, Rezaie S (2011) A Sensitive and specific PCR based method for identification of Cryptosporidium sp. using new primers from 18S Ribosomal RNA. Iran J Parasitol 6(4):1-7

36. Kumar S, Strecher G, Tamura K (2016) MEGA7: molecular evolutionary genetics analysis version 7.0 for bigger datasets. Mol Biol Evolut 33:1870-1874

37. Ramo A, Del Cacho E, Sánchez-Acedo C, Quílez J (2017) Occurrence of Cryptosporidium and Giardia in raw and finished drinking water in northeastern Spain. Sci Total Environ 580:1007-1013. https://doi.org/10.1016/j. scitotenv.2016.12.055

38. Keeley A, Faulker BR (2008) Influence of land use and watershed characteristics on protozoa contamination in a potential drinking water resources reservoir. Water Res 42(10-11):2803-2813. https://doi. org/10.1016/j.watres.2008.02.028

39. Srisuphanunt M, Karanis P, Charoenca N, Boonkhao N, Ongerth JE (2010) Cryptosporidium and Giardia detection in environmental waters of southwest coastal areas of Thailand. Parasitol Res 106:1299-1306. https://doi. org/10.1007/s00436-010-1795-0

40. Swaffer BA, Vial HM, King BJ, Daly R, Frizenschaf J, Monis PT (2014) Investigating source water Cryptosporidium concentration, species and infectivity rates during rainfall-runoff in a multi-use catchment. Water Res 67:310-320. https://doi.org/10.1016/j.watres.2014.08.055

41. Mahmoudi MR, Bandepour M, Kazemi B, Mirzaei A (2017) Detection and enumeration of Cryptosporidium in environmental water samples by Realtime PCR assay. J Bas Res Med Scie 4(3):42-47

42. de Souza MS, O'Brien C, Santin M, Jenkins M (2019) A highly sensitive method for detecting Cryptosporidium Parvum oocysts recovered from source and finished water using RT-PCR directed to Cryspovirus RNA. J Microbiol Methods. https://doi.org/10.1016/j.mimet.2018.11.022

43. Xiao S, An W, Chen Z, Zhang D, Yu J, Yang M (2012) Occurrences and genotypes of Cryptosporidium oocysts in river network of Southern-Eastern China. Parasitol Res 110(5):1701-1709. https://doi.org/10.1007/s0043 6-011-2688-6

44. Ongerth JE (2013) The concentration of Cryptosporidium and Giardia in water-the role and importance of recovery efficiency. Water Res 47(7):2479-2488. https://doi.org/10.1016/j.watres.2013.02.015

45. Yang R, Murphy C, Song Y, Ng-Hublin J, Estcourt A, Hijjawi N, Chalmers R, Hadfield S, Bath A, Gordon C, Ryan U (2013) Specific and quantitative detection and identification of Cryptosporidium hominis and C. parvum in clinical and environmental samples. Exp Parasitol 135(1):142-147. https:// doi.org/10.1016/j.exppara.2013.06.014

46. Hanninen M, Horman A, Rimhanen-Finne R, Vahtera H, Malmberg S, Herve S, Lahti K (2005) Monitoring of Cryptosporidium and Giardia in the Vantaa river basin, southern Finland. Int J Hyg Environ Health 208(3):163171. https://doi.org/10.1016/j.ijheh.2005.01.026

47. Coupe S, Delabre K, Pouillot R, Houdart S, Santillana-Hayat M, Derouin F (2006) Detection of Cryptosporidium, Giardia and Enterocytozoon bieneusi in surface water, including recreational areas: a one-year prospective 
study. FEMS Immunol Med Microbiol 47(3):351-359. https://doi. org/10.1111/j.1574-695X.2006.00098.x

48. Plutzer J, Karanis P, Domokos K, Torokne A, Marialigeti K (2008) Detection and characterisation of Giardia and Cryptosporidium in Hungarian raw, surface and sewage water samples by IFT, PCR and sequence analysis of the SSUrRNA and GDH genes. Int J Hyg Environ Health 211(5-6):524-533. https://doi.org/10.1016/j.ijheh.2008.04.004

49. Castro-Hermida JA, Garcia-Presedo I, Almeida A, Gonzalez-Warleta M, Da Costa JMC, Mezo M (2008) Presence of Cryptosporidium spp. and Giardia duodenalis through drinking water. Sci Total Environ 405(1-3):45-53. https://doi.org/10.1016/.jscitotenv.2008.06.040

50. Stokdyk JP, Spencer SK, Walsh JF, de Lambert JR, Firnstahl AD, Anderson AC, Rezania LW, Borchardt MA (2019) Cryptosporidium incidence and surface water influence of groundwater supplying public water systems in Minnesota, USA. Environ Sci Technol 53(7):3391-3398. https://doi. org/10.1021/acs.est.8b05446

51. Chique C, Hynds PD, Andrade L, Burke L, Morris D, Ryan MP, O'Dwyer J (2020) Cryptosporidium spp in groundwater supplies intended for human consumption - a descriptive review of global prevalence, risk factors and knowledge gaps. Water Res 176:115726. https://doi.org/10.1016/j.watre s.2020.115726

52. Mavridou A, Pappa O, Papatzitze O, Dioli C, Kefala AM, Drossos P, Beloukas A (2018) Exotic tourist destinations and transmission of infections by swimming pools and hot springs-a literature review. Int J Environ Res Public Health 15(12):E2730. https://doi.org/10.3390/ijerph15122730

53. DiCesare EA, Hargreaves BR, Jellison KL (2012) Biofilm roughness determines Cryptosporidium parvum retention in environmental biofilms. Appl Environ Microbiol 78(12):4187e4193. https://doi.org/10.1128/AEM.08026 $-11$

54. Wolyniak EA, Hargreaves BR, Jellison KL (2010) Seasonal retention and release of Cryptosporidium parvum oocysts by environmental biofilms in the laboratory. Appl Environ Microbiol 76(4):1021e1027. https://doi. org/10.1128/AEM.01804-09

55. DiCesare EA, Hargreaves BR, Jellison KL (2012) Biofilms reduce solar disinfection of Cryptosporidium parvum oocysts. Appl Environ Microbiol 78(12):4522e4525. https://doi.org/10.1128/AEM.08019-11

56. Heo I, Dutta D, Schaefer DA, lakobachvilli N, Artegiani B, Sachs N, Boonekamp KE, Bowden G, Hendrickx APA, Willems RJL, Peter PJ, Riggs MW, O'Connor R, Clevers H (2018) Modelling Cryptosporidium infection in human small intestinal and lung organoids. Nat Microbiol 3(7):814-823. https://doi.org/10.1038/s41564-018-0177-8

57. Aldeyabi HM, Karanis P (2016) Electron microscopic observation of the early stages of Cryptosporidium parvum asexual multiplication and development in in vitro axenic culture. Parasitol 143:749-761. https://doi. org/10.1017/S0031182016000275

58. Roser M, Ritchie H (2016) "Burden of Disease". Published online at OurWorldlnData.org. https://ourworldindata.org/burden-of-disease. Accessed 30 May 2020

59. Fischer EM, Sedlacek J, Hakins E, Knutti R (2014) Models agree on forced response pattern of precipitation and temperature extremes. Geophys Res Lett 41:8554-8562. https://doi.org/10.1002/2014GL062018

60. Mekonnen MM, Hoekstra AY (2016) Four billion people facing severe water scarcity. Sci Adv 2(2):e1500323. https://doi.org/10.1126/sciad v.1500323

61. Dawe D, Moya P, Valencia S (2009) Institutional, policy and farmer responses to drought: el Niño Events and rice in the Philippines. Disasters 33(2):291-307. https://doi.org/10.1111/j.1467-7717.2008.01075.x

62. Stueker MF, Tigchelaar M, Kantar MB (2018) Climate variability impacts on rice production in the Philippines. PLoS One. 13(8):e0201426. https://doi. org/10.1371/journal.pone.0201426

63. Curriero FC, Patz JA, Rose JB, Lele S (2001) The association between extreme precipitation and waterborne disease outbreaks in the United States, 1948-1994. Am J Public Health 91(8):1 194-1199. https://doi. org/10.2105/ajph.91.8.1194

64. Cann KF, Thomas DR, Salmon RL, Wyn-Jooones AP, Kay D (2012) Extreme water-related weather events and waterborne disease. Epidemiol Infect 141(4):671-686. https://doi.org/10.1017/S0950268812001653
65. Hinrichsen D (1989) Living on the Edge. Earthwatch 35:2

66. Rivera WL, Yason JADL, Rivera PT (2005) Serologic detection of cryptosporidiosis among Filipino cancer patients. Parasitol Res 98:75-76. https ://doi.org/10.1007/s00436-005-0014-x

67. Utami WS, Murhandarwati EH, Artama WT, Kusnanto H (2020) Cryptosporidium infection increases the risk for chronic diarrhea among people living with HIV in Southeast Asia: a systematic review and meta-analysis. Asia Pac J Public Health 32(1):8-18. https://doi.org/10.1177/1010539519 895422

68. Berahmat R, Mahami-Oskouei M, Rezamand A, Spotin A, Aminisani N, Ghoyounchi R, Madadi S (2017) Cryptosporidium infection in children with cancer undergoing chemotherapy: how important is the prevention of opportunistic parasitic infections in patients with malignancies? Parasitol Res 116(9):2507-2515. https://doi.org/10.1007/s00436-017-5560-5

69. Esteghamati A, Khanaliha K, Bokharaei-Salim F, Sayyahfar S, Ghaderipour M (2019) Prevalence of intestinal parasitic infection in cancer, organ transplant and primary immunodeficiency patients in Tehran, Iran. Asian Pac J Cancer Pre 20(2):495-501. https://doi.org/10.31557/APJCP.2019.20.2.495

70. Fishcer RT, Day JC, Wasserkrug H, Faseler M, Kats A, Daniel JF, Slowik V, Andrews W, Hendrickson RJ (2020) Complications of Cryptosporidium infection after pediatric liver transplantation: diarrhea, rejection, and biliary disease. Pediatr Transplant 10:e13807. https://doi.org/10.1111/ petr.13807

71. Iqbal A, Lim YAL, Surin J, Sim BLH (2012) High diversity of Cryptosporidium subgenotypes identified in Malaysian HIV/AIDS individuals targeting gp60 gene. PLoS ONE 7(2):e31139. https://doi.org/10.1371/journ al.pone.0031139

72. Sulżyc-Bielicka V, Kołodziejczyk L, Jaczewska S, Bielicki D, Safranow K, Bielicki P, Kładny J, Rogowski W (2018) Colorectal cancer and Cryptosporidium spp. infection. PLoS One 13(4):e0195834. https://doi.org/10.1371/journ al.pone.0195834

73. Kopacz Z, Kváč M, Karpiński P, Hendrich AB, Sąsiadek MM, Leszczyński P, Sak B, McEvoy J, Kicia M (2019) The first evidence of Cryptosporidium meleagridis infection in a colon adenocarcinoma from an immunocompetent patient. Front Cell Infect Microbiol 9:35. https://doi.org/10.3389/ fcimb.2019.00035

74. Pumann P, Kožǐšek F, Craun GF, Kunde TR, Malý M, Frost FJ, Čeřovská L (2019) High serological response to Cryptosporidium-specific antigens in the Czech Republic and its Association with water supply. J Water Health 17(5):691-700. https://doi.org/10.2166/wh.2019.061

75. Center for Disease Control (2007) Cryptosporidiosis outbreaks associated with recreational water use-five states, 2006. MMWR Morb Mortal Wkly Rep 56(29):729-732

76. Widerström M, Schönning C, Lilja M, Lebbad M, Ljung T, Allestam G, Ferm M, Björkholm B, Hansen A, Hiltula J, Långmark J, Löfdahl M, Omberg M, Reuterwall C, Samuelsson E, Widgren K, Wallensten A, Lindh J (2014) Large outbreak of Cryptosporidium hominis infection transmitted through the public water supply, Sweden. Emerg Infect Dis 20(4):581-589. https:// doi.org/10.3201/eid2004.121415

77. DeSilva MB, Schafer S, Kendall Scott M, Robinson B, Hills A, Buser GL, Salis K, Gargano J, Yoder J, Hill V, Xiao L, Roellig D (2013) Hedberg K (2016) Communitywide cryptosporidiosis outbreak associated with a surface water-supplied municipal water system-Baker City, Oregon. Epidemiol Infect 144(2):274-284. https://doi.org/10.1017/S0950268815001831

78. Flugelman AA, Dubnov J, Jacob L, Stein N, Habib S, Rishpon S (2019) Epidemiologic surveillance in Israel of Cryptosporidium, a unique waterborne notifiable pathogen, and public health policy. Isr Med Assoc J 21(9):589-594

\section{Publisher's Note}

Springer Nature remains neutral with regard to jurisdictional claims in published maps and institutional affiliations. 